Entrepreneurship and social networks in IT sectors: the case of the software industry

Isabel Salavisa

Pedro Videira

Filipa Santos

Dezembro de 2008

WP no 2008/74

DOCUMENTO DE TRABALHO

WORKI NG PAPER 


\section{Entrepreneurship and social networks in IT sectors: the case} of the software industry

Isabel Salavisa^

Pedro Videira^

Filipa Santos^

WP no 2008/74

Dezembro de 2008

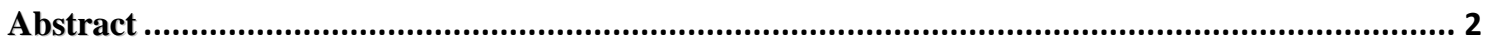

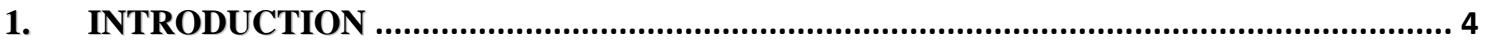

2. BACKGROUND

3. THEORETICAL FRAMEWORK

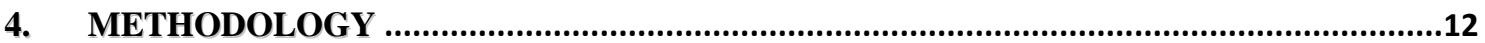

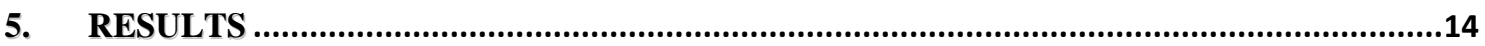

5.1. THE IMPORTANCE OF ENTREPRENEURS' PERSONAL NETWORKS TO ENTREPRENEURIAL PERFORMANCE.......................................................................................14

5.2. THE 13 COMPANIES' GROUP: CHARACTERIZATION AND NETWORKS ......................15

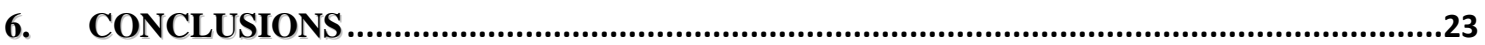

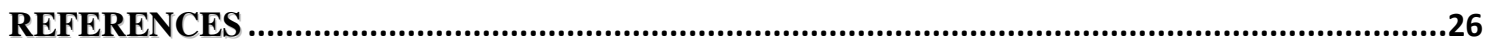

This research was carried out within the Project ENTSOCNET - Social networks, entrepreneurs and access to knowledge: the case of biotechnology and the IT industries, funded by FCT - Fundação para a Ciência e a Tecnologia (POCI/ESC/60500/2004), Portugal.

^DINÂMIA / ISCTE-IUL, Lisbon, Portugal, www.dinamia.iscte.pt. 


\section{Abstract}

Empirical research has repeatedly confirmed that social networks are important for the creation, survival and growth of new companies. In this article, the leading research questions are: 1) how do networks contribute to the creation of software firms and further development of a competitive IT sector; 2) what is the structure and features of those networks; 3) how have they evolved from the companies' founding stage to the current period; 4) what resources (scientific and technological knowledge, skills, and others) do entrepreneurs mobilize through their networks. Based on a survey of 13 companies, those research questions have been tested, using a methodology that combines applied statistical techniques and social network analysis. Our results seem to support our research questions. They also show that some companies and research units play a relevant role as brokers in the access of many companies to technological, informational and other resources.

\section{Résumé}

L'évidence empirique a montré à plusieurs reprises l'importance des réseaux personnels des entrepreneurs pour la création et la réussite des entreprises. Dans cet article, les questions de recherche fondamentales sont: 1) quel est le rôle des réseaux sociaux dans la création des entreprises du secteur du logiciel pour les télécommunications; 2) quelles sont la structure et les caractéristiques de ces réseaux; 3) quelle a été l'évolution de ces réseaux depuis leur création jusqu'à présent; 4) quelles sont les ressources (connaissances scientifique et technologique, qualifications, etc.) et les sources mobilisées par les entrepreneurs à travers les réseaux. Nous avons procédé au test de nos hypothèses sur un groupe de 13 entreprises du secteur, ayant recours à une méthodologie qui combine les techniques statistiques et l'analyse des réseaux sociaux. Les résultats semblent confirmer nos questions de recherche. Par ailleurs, ils révèlent l'existence de quelques entreprises et organisations de recherche qui assurent un rôle d'intermédiaires, permettant l'accès à nombre d'entreprises aux ressources technologiques et informationnelles fondamentales.

Key words: Entrepreneurship, social network analysis, firm creation, IT subsector, software industry.

JEL classification: L26, M13, L86, L96 


\section{Graphs}

Graphs 1 and 2 - Importance of personal networks

Graph 3 - Average intensity of contacts in the two periods

\section{$\underline{\text { Tables }}$}

Table 1 - Total number of workers

Table 2 - Turnover in 2007

Table 3 - Comparison between strong and weak links in the two periods

Table 4 - Network centrality measures in the two periods

Table 5 - Networks' dynamic over the two periods

Table 6 - Composition of the networks

\section{Diagrams}

Diagram 1 - Entrepreneurs' networks at the founding stage of the 13 companies

Diagram 2 - Entrepreneurs' networks in the development stage of the 13 companies (2008) 


\section{INTRODUCTION}

The research presented in this paper aims to clarify the role played by entrepreneurs' social networks in knowledge-intensive industries through the creation and early growth of companies in IT sectors. In this paper we will focus on the software sector, and more specifically on the companies that produce software for telecommunications. Since large software houses are diversified, we have extended our study to the entire sector, excluding multinational companies.

Three questions have guided our research effort: (i) how do entrepreneurs' social networks affect the access to and mobilization of relevant scientific and technological knowledge and skills, thereby enabling the founding of new companies and helping to sustain their subsequent competitive and innovative performance; (ii) what is the structure and features of those networks and their contribution to the emergence of a competitive IT sector; (iii) how have those networks evolved from the founding stage to the current period.

IT companies are much less dependent on new scientific breakthroughs than, for instance, biotechnology companies. To succeed they depend on technological expertise, ability to discover opportunities and create innovative products, devices and solutions and professional skills. Entrepreneurs' social networks are crucial to business founding and first stages performance, and their main role is to access and mobilize technological knowledge, management knowledge and information on market opportunities and funding sources as well as skilled workers. Here, the mobility of skilled workers between companies is most relevant and spin-offs usually originate from incumbent companies, although a few successful cases are academic spin-offs.

Our approach has drawn on recent research on the role of social networks and was carried out using a blended methodology, applying statistical techniques and social networks analysis to a survey of 13 out of the most important Portuguese software for telecommunications companies. Our purpose is to shed light on the multiplicity of contributions of entrepreneurs' social networks to the company; on the origins, forms, characteristics and evolution of those networks; and on the strategies adopted by companies, on a later stage, to leverage the knowledge thus obtained as well as to transform personal networks into companybased relations.

The structure of the paper is as follows: after a brief theoretical discussion on networks and entrepreneurs (sections 2 and 3), we will present our research questions and methodology (section 4). Then we will proceed to the presentation of the results (section 5), regarding the analysis of the social networks of entrepreneurs, and including a short presentation of the 
software for telecommunications companies. Finally, in section 6, we will draw some conclusions. 


\section{BACKGROUND}

The role of entrepreneurs has been mentioned in economic theory since the $18^{\text {th }}$ century (see Cantillon, 1755), but its definition was at the time wide-ranging and abstract. Since then some authors gave contributions, but we will focus on those of the $20^{\text {th }}$ century, mainly by Schumpeter (1942) and by Kirzner (1982). The first Schumpeterian definition portrays the entrepreneur as the one who has "entrepreneur spirit", namely leadership and vision; his second definition focused on a collective agent, the enterprise, that is endowed with knowledge, capabilities, skills and resources to turn the invention into innovation by carrying it out successfully into practice. Entrepreneurship is matched with innovation, a new combination of existing resources which introduction causes disequilibrium in the market. The entrepreneur is at the centre of economic dynamics: "No entrepreneur - no innovation - no dynamics - no evolution” (Grebel, Pyka and Hanusch, 2003). In turn, Kirzner conceives of the entrepreneur as an arbitrageur who discovers profit opportunities in the market, thus contributing to equilibrium. He corrects temporary errors in the price system and takes advantage of the imperfections of knowledge.

As the entrepreneurs' main traits, Schumpeterian entrepreneurs have certain psychological traits such as heroic imagination, aggression and a desire to prove their own worth. Shane (2003) identifies three personality characteristics of the entrepreneur: absorptive capacity, intelligence and cognitive abilities. He also names three main ways of obtaining better information to use in the entrepreneurial activity: life experiences, social networks and research processes. Several other authors hypothesized a positive relationship between entrepreneurship (venture creation) and certain personal attributes such as locus of control, need of achievement, personal optimism, preference for shaping one's own destiny and tolerance for ambiguity (see a synthesis in Carolis and Saparito, 2006).

Shane (2003) defines entrepreneurship according to the "individual-opportunity nexus" in the sense that the entrepreneurial activity depends upon the interaction between the characteristics of opportunities and the individual characteristics of the agents who exploit them (personality factors, assessment of risk and skills to organize the processes of discovery, evaluation and exploitation of opportunities). In a sketchy way, most entrepreneurial activities entail either the founding of a new company or self-employment.

In this framework, opportunity appears as a pivotal point. In the same line, a number of authors, not to mention Kirzner, have dealt with a pre-existent opportunity when addressing entrepreneurship (Casson and Wadeson, 2007; Dubini and Aldrich, 1991). Contrarily, the Schumpeterian entrepreneur creates the opportunities himself, resorting to ideas and knowledge 
from outside the economic sphere (see Buenstorf, 2006). Besides opportunity and innovation, other elements referred to as crucial include uncertainty (central to Kirzner), responsibility and judgemental decisions (Hébert and Link, 1989).

In this study we have used network analysis to study entrepreneurship in a high-tech sector, having resorted to social network analysis since our units are individuals and their personal connections. This option was initially taken due to the apparent fact that this kind of sector relies strongly on complex sophisticated knowledge which creation entails collaborative efforts across diverse and multiple entities, mostly companies and academic research centres, and requires a rapid circulation of ideas in the professional community.

In taking this option, we were driven to a vast and fast growing theoretical domain whose origins are to be found in other - than economics - social sciences and whose main current applications are to be looked for mainly in sociology, psychology and entrepreneurship studies. In recent years, however, there has been a dramatic increase in the number of innovation studies applying this approach with a more or less intense use of its tools and potentialities.

Networks consist of a way of modelling social structures. Scott writes that "social network analysis is an orientation towards the social world that inheres in a particular set of methods. It is not a specific body of formal or substantive social theory.” (2000:37). As such, their potential application is presumably quite broad. Social network analysis is a powerful tool to analyze social relations, and was founded in the 1960s drawing on the work of social anthropologists and social psychologists over the 1930s. First social network studies were focused on small communities, on kinship relations or work relations.

A vast literature has developed since, but it was not until the 1990s that it began being extensively used to study economic phenomena such as entrepreneurship (see Sousa, 2008, for a review of the literature), innovation and scientific knowledge creation and diffusion.

The main reasons underlying this development of network analysis are both theoretical and factual. Theoretical reasons encompass the need to incorporate systematic contextualization of human agency and social and economic phenomena, and to adopt systemic approaches. Factual reasons concern the observed real phenomena, and include the need to deal with complex processes and to overcome the shortfalls of increased scientific specialization.

The contextualization reason refers to the acknowledged necessity to study human agency and social phenomena within their context, meaning that no single social entity exists without and outside its social relations. A case in view is the firm, and a new generation of studies on the subject. A second case regards the entrepreneur, its standing and role in economic 
theory (see Hébert and Link, 1989; Grebel, Pyka and Hanusch, 2003; Granovetter, 1985, and the assertion of embeddedness). Another aspect of the relational context provided by the networks approach is that it takes into consideration the "threads of continuity linking actions across a field of action that includes individuals, organizations, and environment as a totality" (Dubini and Aldrich, 1991:306).

The second theoretical reason concerns "systemicity". Borgatti and Foster (2003) claim that a shift has occurred from the individualistic, essentialist and atomistic explanations toward a much more contextual, relational, systemic approach. This trend is clear in innovation studies with the adoption of a systems approach in theoretical analyses.

Among factual reasons, stands the complexity of core processes such as the current process of advanced knowledge creation. According to Powell and Grodal, large scale scientific research is more and more conducted by communities that are multinational, multiorganizational, multiskilled, network-based, and where collaboration and rivalry coexist (Powell and Grodal, 2005). It is very significant that the first example given by the authors to illustrate this tendency is that of the human genome sequentiation, successfully conducted separately and in parallel by two distinct teams, a public and a private one, both organized as large-scale networks. Another example is the open source software movement.

A second factual reason is increased specialization, which has become a common trait to most human activities and, in a way, is as much a cause as a consequence of economic progress (via productivity and wealth growth), social progress (via better medical services, for instance), scientific and technological advances, sports performances and so on. At the business level, specialization has both permitted and required the spread of companies' networks (see Williamson, 1975).

Technological breakthroughs have permitted, together with transformations in the markets, a reorganization of companies, increasingly focused on their core business and resorting intensively to the outsourcing of services and goods. Large companies have split their operations and partially delocalized them to other regions or countries. Their different sites are connected by internal networks and outwards to suppliers and customers. Almost all have engaged in increased interactions with suppliers, customers, competitors, public agencies, universities and research centres, technological experts, business services, finance companies and the worldwide web. This "back to the marketplace" trend entails a bigger exposure to uncertainty and to opportunism, both present in market transactions (see Coase and Williamson). The establishment of long-term relations based on predictability and mutual trust could help lessening those problems (see Dubini and Aldrich, 1991). 
In short, network analysis could then be a tool to help shedding light on economic phenomena, such as company studies, entrepreneurship, innovation and the creation of knowledge.

\section{THEORETICAL FRAMEWORK}

One of our major concerns was to understand how a technologically advanced sector emerges and consolidates, through the process of firm creation, survival, growth and/or exit.

As empirical evidence has repeatedly confirmed, the characteristics of the sector under study are crucial, as well as its maturity stage, since opportunities and the likelihood of entry success vary across industries and over time (Shane, 2003).

Product life cycle approaches are useful to help thinking theoretically the interconnection of regularities regarding entry, growth and exit of firms; market structure and its evolution; and the dynamics of innovation (see Klepper, 1996; Shane, 2003).

Although not a new industry, the software industry continues benefitting from a high level of technological opportunity and a high growth demand. Diversity in demand and low entry barriers into some of its segments allow for a niche exploitation strategy. This applies to sectors that are specialized in non standardized specific products, combining a strong innovative product dynamics and a close interaction with customers, to offer adapted or even tailor-made solutions. This is the case of our sector (software for telecommunications), where offerings meet a fast growing and changing demand, which draws on major current shifts standing in higher human mobility, higher contacts frequency and novelty preference.

The notion of entrepreneur we adopt in this research study combines the ideas of being the main founder of the company (nowadays he still is the CEO or the head of the board of the company), the innovator who gathers and combines the existing resources (capital, human and knowledge resources), and the leader who copes with uncertainty in the market and who exploits the opportunity. In doing that, he resorts to personal networks, both at the company's founding period and later on.

We have also explored the idea of the entrepreneur obtaining a significant part of the resources necessary for his company to be successful through his social network. The entrepreneur can either establish contact with his personal entourage, such as family and close friends, or with former university colleagues, former co-workers and acquaintances. This personal network (informal) is most important at the early stage (start-up) of the company foundation (Bruderl and Preisendorfer, 1998), which is a period characterized by the lack of capital and human resources as well as a high level of uncertainty. Family and friends may 
provide the emotional support and initial funding, in order to motivate the entrepreneur to pursue and achieve innovation and drive the company to a mature stage.

This is in line with the network founding hypothesis, which claims that networking resources, networking activities and networking support are heavily used to establish new businesses, and thus social networks stimulate entrepreneurship (Burt, 1992). In other words, entrepreneurs who have access to a broader and diverse network, and receive support from this network, are more successful and their companies have greater opportunities to survive from the start-up phase and proceed to a mature phase.

Being a spin-off from another organization (such as a bigger company or a university or a research centre) can also represent an important factor for the survival and success of the new companies. Parent organizations can help their spin-offs in numerous ways such as a) funding and access to capital, b) sharing the costs of skilled personnel and R\&D, and c) as a source of network links that reduce the search costs for partners (Mustar et al., 2006).

When the company reaches maturity, after having succeeded in launching the innovative product or process, the formal network of the company (namely constituted by, banks, lawyers, government agencies, partners and clients) becomes more important as a means to commercialize and internationalize innovative ideas (Bruderl and Preisendorfer, 1998). It has been suggested that small networks are more relevant at the start-up phase, because the entrepreneur needs strong support from close relationships; whereas at the development phase, signalling new business opportunities is crucial and then large networks with weaker ties are more appropriate to the circulation of information (Birley, 1985).

To sum up, all the literature that associates entrepreneurship to social networks shares the idea that social networks are important to obtain resources and that the availability of those resources enhances the survival likelihood and growth prospective of the company. The most important resources sought by the entrepreneur are innovation and scientific and technological knowledge (crucial in this knowledge-intensive sector), management knowledge, decisionmaking support, information on market opportunities and access to funding, as well as skilled workers.

Our networks differ according to the agents involved in as well as to their size, density, purpose, content and relevance (see Hite and Hesterly, 2001). While more 'open' social networks, with many weak ties (and indirect ties) are crucial to access novel, non-redundant information, avoiding the risk of too much closeness in a network (Granovetter, 1973), denser 'closed' networks, characterized by strong ties with high-levels of trust, facilitate the exchange of in-depth and tacit knowledge (Coleman, 1990; Sorenson, Rivkin and Fleming, 2006). Not 
only the structure of the network, but also the position of the actor in that network, may constitute a strategic advantage for the companies, particularly for those located in structural holes, that function as 'brokers' between otherwise unconnected companies (Burt, 1992).

In order to introduce the time dimension in our study, we have split the new businesses establishment process into two different phases: phase 1 - founding stage of the companies (first two years); phase 2 - company development stage (at present). The motivations, incentives, abilities and resources differ over the two stages and so do social networks.

According to our aims and theoretical framework, the hypotheses explored in this article were:

Hyp. 1) Social networks are important in business creation.

Hyp. 2) Entrepreneurs' personal networks were more crucial for the company during its early stage than a few years later.

Hyp. 3) Social networks configuration have evolved along the different stages of the company's life.

Hyp. 3 a) At the company's founding stage entrepreneurs have more 'closed' social networks, with stronger ties.

Hyp. 3 b) Nowadays entrepreneurs have more 'open' social networks, with more weak ties. 


\section{METHODOLOGY}

We have collected data through in-depth face-to-face interviews with experts and with entrepreneurs of 30 companies of this software subsector in Portugal, throughout 2008. Those interviews were guided by semi-structured questionnaires - one aiming to obtain information about the characteristics of the company's creation process, its present resources and competences and its organizational strategy; the other aiming to obtain information concerning the entrepreneurs' CV and their personal networks, used to access several types of relevant knowledge and information, both at the company's founding stage and at present. For obvious deontological reasons, the respondents and their companies are designated by numbers from 1 to 30. The organizations to which they are connected with are designated by their own names.

Data were analyzed through a combination of statistical tests and network measures (using UCINET ${ }^{1}$ ). The entrepreneurs were asked to assess (within a 7 point scale - from not important to very important) the contribution of the members of their own personal network (friends, family and acquaintances) for the performance of their company and their own performance in two points in time (foundation and at present). We have tested the differences between means using a T-Student test.

In the interviews entrepreneurs were asked: a) to identify the individuals, as well as their institutional affiliation, to whom they usually asked for inputs and advice about four different types of knowledge - innovation (new ideas and also the identification of new business opportunities), scientific and technological knowledge, management and decision-making (concerning the most crucial and strategic decisions for the company); and b) to state the frequency of the contacts with those individuals (within a 5 point scale - from daily to yearly).

The four input squared matrices of UCINET were obtained through the aggregation of the four different types of knowledge, and made of weighted values. The networks presented are ego-networks with valued and directed ties. The directedness of the tie is symbolized by an arrow which points to the source of the knowledge that the entrepreneur is seeking and its value is reflected in the intensity of the tie. The level of intensity has been depicted in the literature of inter-organizational networks as a function of two factors: the amount of resources exchanged and the frequency of contact between two organizations (Zhao and Aram, 1995).

\footnotetext{
${ }^{1}$ UCINET is a social network analyses software created by Steve Borgatti. It is a useful tool to analyze networks, its configuration and its characteristics. We use it mostly to calculate network centrality measures. However, UCINET has other analyzing options. There are other tools also useful for the same purpose such as GUESS, VISONE and PAJEK. We've chosen UCINET because it is a user-friendly tool.
} 
The intensity of the relations between a company (through its entrepreneur) and other organizations was thus obtained by using two methods: the frequency of contacts and the type and number of resources that flow through a certain tie. In the first case, we've taken into account the highest frequency of contact between a company and another organization, regarding all types of resources interchanged. In the second case, we attributed a weak intensity when a company obtains only one type of knowledge through that contact; and a strong intensity when a company obtains at least two (if it includes innovation and/or S\&T knowledge) or more types of knowledge. Then we have two matrices, one for the founding period and another for the present one.

The measures used to characterize the networks are: a) centrality - degree, closeness, and betweenness; b) centralization - degree (see Scott, 2000; Wasserman and Faust, 1994).

As to centrality, the degree is the number of ties to other actors in the network. The most central company is the one that has the highest number of ties (links/connections) with other companies/organizations, which might mean that this company receives more information than all of the others. The closeness indicates how close an individual is to all other individuals in a network (directly or indirectly). There are companies that are in the centre of the network and others are in the periphery; it means that the most central companies are in a privileged position to receive more information than the ones that are in the periphery. And finally the betweenness measures the extent to which a node lies between other nodes in the network: a node with few ties may play an important intermediary role and so be very central to the network. Then, the betweenness of a node indicates whether an agent can play the role of a broker or gatekeeper with a potential for control over others. Broker companies have important, non-redundant information to give to other companies that without this connection would be isolated from the knowledge network.

The centralization measures describe the extent to which the network is centralized around a certain node or a few particular focal points.

We also analysed the percentage of strong and weak links according to the frequency measure and the percentage of links to different types of organizations - universities, IT companies, non-IT companies (such as banks and accountancy companies) and others (e.g. business associations and others).

In order to compare the entrepreneurs' networks between the founding stage and the present time, we had to focus on a group of companies that were created in the same period, thus permitting a consistent comparison. Out of the 30 respondents, we selected those (13) that were founded between 1999 and 2001, the peak years for start-ups in this industry in Portugal. 


\section{RESULTS}

\subsection{THE IMPORTANCE OF ENTREPRENEURS' PERSONAL NETWORKS TO ENTREPRENEURIAL PERFORMANCE}

Entrepreneurs were asked to assess the importance of their personal networks (family, close friends and acquaintances) to their companies' performance and to their own, in the two periods under analysis (founding and present time). Because the company relies more on strong ties to obtain resources at its creation and on a large number of weak ties as it evolves, we expected the entrepreneur's personal network to be more important for the performance of the company at the founding stage than at present, and presently more important for the performance of the entrepreneur than for the company's performance.

Our first and second hypotheses were born out by evidence. As to the first, personal networks are more important to the performance of the company in the founding period $(M=5$; $\mathrm{SD}=1.65)$ than at present $(\mathrm{M}=3.6 ; \mathrm{SD}=1.85)(\mathrm{t}=2.209 ; \mathrm{p}=0.05)$. As to the second, at present, personal networks are more important to the entrepreneur's personal performance $(M=4.3$; $\mathrm{SD}=1.84)$ than to the company's $(\mathrm{M}=3.6 ; \mathrm{SD}=1.85)(\mathrm{t}=2.635 ; \mathrm{p}=0.02)$. This means that the foundation stage the entrepreneur's personal network seems more important to the company's performance and later on it becomes more important to the performance of the entrepreneur himself, since the company's development will increasingly rely mostly on weak ties such as contacts with banks, public agencies, other companies, etc.

Graphs 1 and 2 - Importance of personal networks
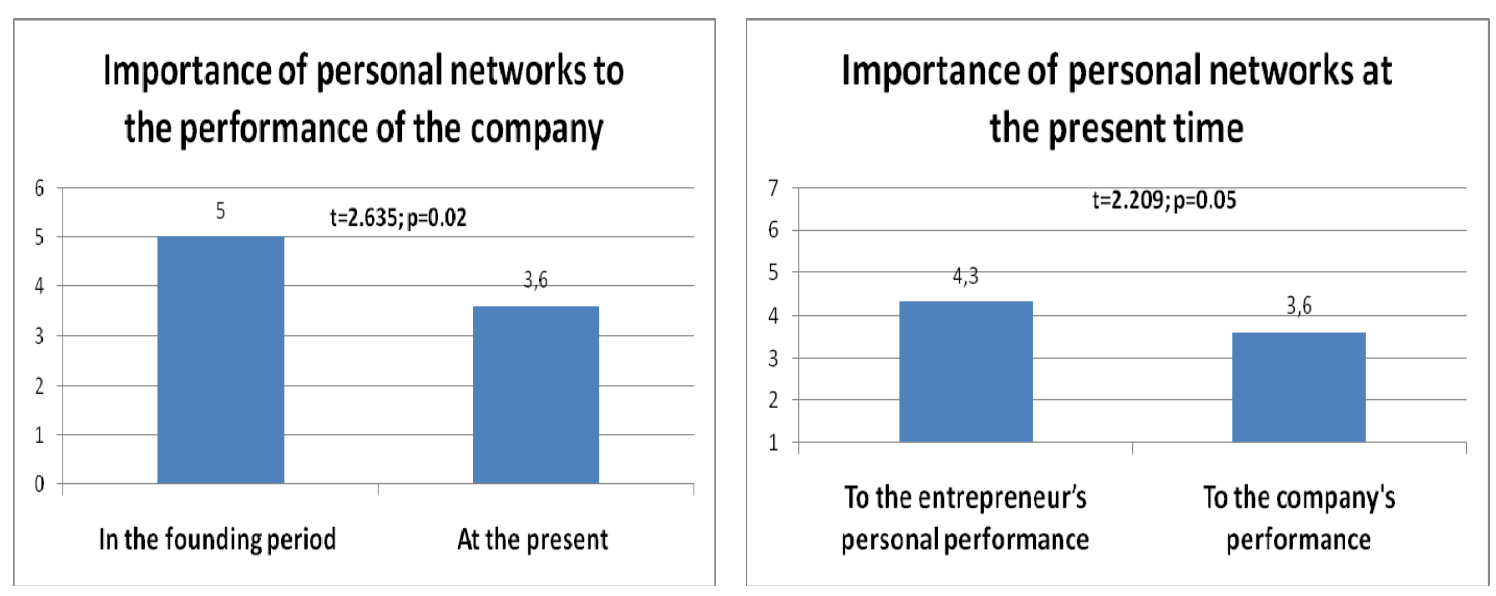


\subsection{THE 13 COMPANIES' GROUP: CHARACTERIZATION AND NETWORKS}

We will keep analysing in detail the subgroup of 13 companies. In fact, as explained above, it allows studying their networks' evolution. Regarding the founding year, 23\% of the 13 companies were created in 1999, 39\% in 2000, and 39\% in 2001. These companies have an average of 3.6 partners (ranging from 1 to 10). They are mostly, but not exclusively, small to medium sized, ranging from less than 10 workers to more than 500 (two companies). The 46\% have a turnover between 1.000.000€ and 5.000.000€. Portugal Telecom (PT) group is the major client for four companies, representing more than $30 \%$ of their total turnover.

Table 1 - Total number of workers

\begin{tabular}{lccc}
\hline & Frequency & Percentage & Valid Percentage \\
\hline$<10$ & 1 & 7,7 & 8,3 \\
10 to 49 & 5 & 38,5 & 41,7 \\
50 to 249 & 4 & 30,8 & 33,3 \\
250 to 499 & 2 & 15,4 & 16,7 \\
Total & 12 & 92,3 & 100,0 \\
Missing & 1 & 7,7 & \\
Total & 13 & 100,0 & \\
\hline
\end{tabular}

Table 2 - Turnover in 2007

\begin{tabular}{lccc}
\hline & Frequency & Percentage & Valid Percentage \\
\hline 200.001 to 500.000 & 2 & 15,4 & 16,7 \\
1.000 .001 to 5.000 .000 & 6 & 46,2 & 50,0 \\
5.000 .001 to 25.000 .000 & 2 & 15,4 & 16,7 \\
25.000 .001 to 50.000 .000 & 1 & 7,7 & 8,3 \\
$>50.000 .000$ & 1 & 7,7 & 8,3 \\
Total & 12 & 92,3 & 100,0 \\
Missing & 1 & 7,7 & \\
Total & 13 & 100,0 & \\
\hline
\end{tabular}

The average age of the entrepreneurs now is $40(\mathrm{SD}=6.6)$ and at the founding period it was 31.5 years. The $31 \%$ of the entrepreneurs hold a degree in engineering and a MBA, while $15 \%$ hold a degree and a post-graduation in engineering. Almost $40 \%$ obtained a degree or a post-graduation in foreign universities and around three quarters have worked or studied abroad 
over a significant period of time. More than half of the entrepreneurs have participated in at least one project or research team.

Out of the 13 companies, $62 \%$ received some kind of public incentive at the founding stage, and $46 \%$ were also publicly supported in the last two years. In what concerns the companies' origins, four of them were spin-offs, two from the Portugal Telecom (PT) group, one from Instituto Nacional de Engenharia de Sistemas e Computadores (INESC) and from Instituto Superior Técnico (IST), both public research organizations, and another one from SONAE, a large and diversified holding that has been expanding into the telecommunications sector; and three were incubated, two in formal incubators (Madan Park and Tagus Park), and one in Inova-Ria, a network of IT companies.

In terms of their global networks in the initial period (diagram 1), the 13 companies had a higher percentage of strong links (76\%) than at the present (58\%). Even if at both periods the percentage of strong links is higher than that of weak links, the proportion of weak links has increased considerably. In fact, only the number of weak ties has increased, more than doubling, as shown in table 3 . This means that hypotheses 3 (3a e 3b) were confirmed.

Table 3 - Comparison between strong and weak links in the two periods

\begin{tabular}{lllll}
\hline & \multicolumn{2}{l}{ At the founding period } & \multicolumn{2}{l}{ At the present time } \\
\cline { 2 - 5 } Companies & $\begin{array}{l}\text { Number } \\
\text { of strong }\end{array}$ & Number of & $\begin{array}{l}\text { Number } \\
\text { of strong }\end{array}$ & Number of \\
ID & links & weak links & links & weak links \\
\hline 5 & 3 & 0 & 0 & 0 \\
8 & 2 & 0 & 3 & 0 \\
9 & 2 & 0 & 1 & 0 \\
11 & 7 & 0 & 4 & 0 \\
12 & 1 & 1 & 1 & 0 \\
13 & 6 & 0 & 4 & 2 \\
14 & 2 & 0 & 0 & 2 \\
15 & 1 & 1 & 4 & 0 \\
17 & 3 & 7 & 0 & 20 \\
18 & 2 & 1 & 1 & 2 \\
19 & 3 & 1 & 9 & 0 \\
22 & 2 & 1 & 4 & 0 \\
23 & 4 & 0 & 6 & 1 \\
\hline Total & 38 & 12 & 37 & 27 \\
Percentage & $76 \%$ & $24 \%$ & $58 \%$ & $42 \%$ \\
\hline
\end{tabular}


In the initial period, there are some dyads as isolate components and the network is quite sparse and unconnected. Company no. 17 has the highest degree of centrality (see table 4) and is the one with most links to universities (6). The other most central companies, in terms of degree and betweenness, are nos. 11 and 13 companies. Although company no. 17 appears as the most central node of the network in the foundation period, this network has a low degree of centralization of $10 \%$.

Table 4 - Network centrality measures in the two periods

\begin{tabular}{|c|c|c|c|c|c|c|c|}
\hline \multicolumn{4}{|c|}{ Centrality measures - At the founding period network } & \multicolumn{4}{|c|}{ Centrality measures - At the present time } \\
\hline Company ID & Degree & Betweenness & Closeness & Company ID & Degree & Betweenness & Closeness \\
\hline 5 & 3 & 3 & 2551 & 5 & 0 & 0 & 3721 \\
\hline 8 & 2 & 37 & 909 & 8 & 3 & 107 & 575 \\
\hline 9 & 2 & 1 & 2602 & 9 & 1 & 0 & 3661 \\
\hline 10 & 7 & 302,167 & 845 & 10 & 4 & 133 & 567 \\
\hline 12 & 2 & 37 & 913 & 12 & 1 & 0 & 3661 \\
\hline 13 & 5 & 232,833 & 881 & 13 & 6 & 302,167 & 537 \\
\hline 14 & 2 & 1 & 2602 & 14 & 2 & 54 & 549 \\
\hline 15 & 2 & 1 & 2602 & 15 & 4 & 159 & 525 \\
\hline 17 & 11 & 474,833 & 841 & 17 & 22 & 1280,5 & 477 \\
\hline 18 & 3 & 73 & 930 & 18 & 3 & 80,5 & 569 \\
\hline 19 & 4 & 201 & 866 & 19 & 6 & 210 & 522 \\
\hline 22 & 3 & 142,167 & 857 & 22 & 4 & 65,167 & 621 \\
\hline 23 & 4 & 108 & 941 & 23 & 7 & 329,667 & 535 \\
\hline ANETIE & 1 & 0 & 2553 & ANJE & 1 & 0 & 629 \\
\hline Anje & 2 & 105 & 897 & Assistudos & 1 & 0 & 576 \\
\hline Assistudos & 1 & 0 & 903 & BPN & 1 & 0 & 591 \\
\hline BPN & 1 & 0 & 918 & $\begin{array}{l}\text { Cabo Verde Telecom } \\
\text { Centro de Pesquisa }\end{array}$ & 1 & 0 & 531 \\
\hline Decathlon & 1 & 0 & 918 & Desenvolvimento & 1 & 0 & 531 \\
\hline Consulting C. & 1 & 0 & 978 & CEO Forum & 2 & 8,5 & 615 \\
\hline Accountancy C. 1 & 1 & 0 & 2553 & Cotec & 2 & 156 & 525 \\
\hline Accountancy C. 2 & 1 & 0 & 946 & Decathlon & 1 & 0 & 591 \\
\hline Accountancy C. 3 & 1 & 0 & 882 & Accountancy C. & 1 & 0 & 589 \\
\hline Accountancy C. 4 & 1 & 0 & 2603 & EFACEC & 1 & 0 & 531 \\
\hline E. de capital de risco & 1 & 0 & 2603 & Free Univ. Amsterdam & 1 & 0 & 589 \\
\hline Eriksson & 2 & 72 & 878 & Geodan & 1 & 0 & 589 \\
\hline Fac. Economia do Porto & 1 & 0 & 967 & Grupo Orange & 1 & 0 & 675 \\
\hline FCCN & 1 & 0 & 2603 & INAG & 1 & 0 & 589 \\
\hline Free Univ. Of Amsterdam & 1 & 0 & 978 & INESC & 1 & 0 & 531 \\
\hline Geodan & 1 & 0 & 978 & Inov.capital & 1 & 0 & 3661 \\
\hline Hewlett Packard & 2 & 141,833 & 856 & Inova-Ria & 1 & 0 & 579 \\
\hline IBM & 1 & 0 & 882 & Instituto de Telecomunicações & 1 & 0 & 531 \\
\hline IESF & 1 & 0 & 903 & Instituto Fraunhofen & 1 & 0 & 589 \\
\hline INESC & 1 & 0 & 878 & IPL - Inst. Politécnico Leiria & 1 & 0 & 629 \\
\hline Inov. Capital & 1 & 0 & 2603 & IST - Inst. Sup. Técnico & 1 & 0 & 3661 \\
\hline Instituto de Telecomunicações & 1 & 0 & 878 & Memotec & 1 & 0 & 531 \\
\hline IST - Inst. Sup. Técnico & 1 & 0 & 2603 & Microsoft & 1 & 0 & 621 \\
\hline Lusomundo & 1 & 0 & 882 & Mobile Metamed & 1 & 0 & 576 \\
\hline
\end{tabular}




\begin{tabular}{|c|c|c|c|c|c|c|c|}
\hline Multisector & 1 & 0 & 2553 & Nokia & 1 & 0 & 621 \\
\hline Optimus & 2 & 56 & 878 & Novabase & 1 & 0 & 591 \\
\hline Oracle & 1 & 0 & 878 & Optimus & 2 & 32,667 & 585 \\
\hline Philips & 1 & 0 & 950 & PT - Portugal Telecom & 2 & 0 & 526 \\
\hline PT - Portugal Telecom & 2 & 72 & 874 & PT SI & 1 & 0 & 576 \\
\hline SONAE & 3 & 197,167 & 860 & Schmidt & 1 & 0 & 531 \\
\hline TMN & 2 & 205 & 844 & Simbioz & 1 & 0 & 579 \\
\hline UBS & 1 & 0 & 882 & SONAE & 2 & 32,667 & 585 \\
\hline Univ. Aveiro & 1 & 0 & 878 & Strategical Consulting & 1 & 0 & 579 \\
\hline Univ. Católica & 1 & 0 & 2603 & TMN & 2 & 169,5 & 523 \\
\hline Univ. Coimbra & 1 & 0 & 878 & Univ. Americana & 1 & 0 & 623 \\
\hline Univ. Minho & 1 & 0 & 878 & Univ. Aveiro & 1 & 0 & 531 \\
\hline $\begin{array}{l}\text { Univ. Recife } \\
\text { Univ. Trás-0S-montes e Alto }\end{array}$ & 1 & 0 & 967 & Univ. Baía & 1 & 0 & 531 \\
\hline Douro & 1 & 0 & 878 & Univ. Católica & 1 & 0 & 603 \\
\hline \multirow[t]{10}{*}{ Univ. NL } & 2 & 136 & 910 & Univ. Coimbra & 2 & 121 & 525 \\
\hline & & & & Univ. Fernando Pessoa & 1 & 0 & 576 \\
\hline & & & & Univ. Minho & 1 & 0 & 531 \\
\hline & & & & Univ. S. Carlos & 1 & 0 & 531 \\
\hline & & & & Univ. São Paulo & 1 & 0 & 531 \\
\hline & & & & Unicamp. & 1 & 0 & 531 \\
\hline & & & & Unitel & 1 & 0 & 531 \\
\hline & & & & Univ. NL & 4 & 707,333 & 497 \\
\hline & & & & Vivo & 1 & 0 & 531 \\
\hline & & & & Vodafone & 2 & 45,333 & 581 \\
\hline
\end{tabular}

Other important entities functioning as brokers to our entrepreneurs are: the SONAE group, which links nos. 13, 10 and 22 companies; ANJE, a young entrepreneurs' organization, Telecomunicações Nacionais (TMN), the Portuguese main mobile phone operator; HewlettPackard (HP); and Universidade Nova de Lisboa (UNL), a public university. In terms of the relation between the four spin-offs and their parent organizations, they remain intense (whether by the frequency of contacts or the number and type of resources) (see diagrams 1 and 2).

Nowadays, the network is considerably denser (diagram 2), with an increase of $28 \%$ in the number of links. By denser we mean both the increase in the number of ties and in the connectedness of the network. The use of network density measures for comparing networks of different sizes can be quite problematic due to the tendency of larger networks (which is the case here) to have a lower density.

The network has undergone significant changes, in terms of its composition and structure, as $64 \%$ of its present links are new (see diagrams 1 and 2). Among the links that were kept over the two periods (36\%), three quarters have maintained the same intensity (see table 5). 
Table 5 - Networks' dynamic over the two periods

\begin{tabular}{lcccc|ccc}
\hline & $\begin{array}{c}\text { Links at the } \\
\text { founding } \\
\text { period }\end{array}$ & $\begin{array}{c}\text { Links at } \\
\text { the present } \\
\text { time }\end{array}$ & $\begin{array}{c}\text { New } \\
\text { Links }\end{array}$ & $\begin{array}{c}\text { Remaining } \\
\text { Links }\end{array}$ & $\begin{array}{c}\text { Higher } \\
\text { Strenght of } \\
\text { the Tie }\end{array}$ & $\begin{array}{c}\text { Lower } \\
\text { Strenght of } \\
\text { the Tie }\end{array}$ & $\begin{array}{c}\text { Equal } \\
\text { Strenght of } \\
\text { the Tie }\end{array}$ \\
\hline 5 & 3 & 0 & 0 & 0 & 0 & 0 & 0 \\
8 & 2 & 3 & 3 & 0 & 0 & 0 & 0 \\
9 & 2 & 1 & 0 & 1 & 0 & 0 & 1 \\
11 & 7 & 4 & 3 & 1 & 1 & 0 & 0 \\
12 & 2 & 1 & 1 & 0 & 0 & 0 & 0 \\
13 & 6 & 6 & 1 & 5 & 0 & 1 & 4 \\
14 & 2 & 2 & 1 & 1 & 0 & 1 & 0 \\
15 & 2 & 4 & 4 & 0 & 0 & 0 & 0 \\
17 & 10 & 20 & 13 & 7 & 1 & 1 & 5 \\
18 & 3 & 3 & 3 & 0 & 0 & 0 & 0 \\
19 & 4 & 9 & 7 & 2 & 0 & 0 & 2 \\
22 & 3 & 4 & 2 & 2 & 0 & 0 & 2 \\
23 & 4 & 7 & 4 & 3 & 1 & 0 & 2 \\
\hline Total & 50 & 64 & 42 & 22 & 3 & 3 & 16 \\
Percentage & & & $65,63 \%$ & $34,38 \%$ & $13,64 \%$ & $13,64 \%$ & $72,73 \%$ \\
\hline
\end{tabular}

The average intensity of the contacts is nowadays lower $(\mathrm{M}=2.8$; $\mathrm{SD}=0.78)$ when compared to the founding period ( $\mathrm{M}=3.3$; $\mathrm{SD}=0.67)$, thus helping to confirm the idea that while the number of relations mobilized by the entrepreneurs has increased their intensity has decreased.

Graph 3 - Average intensity of contacts in the two periods

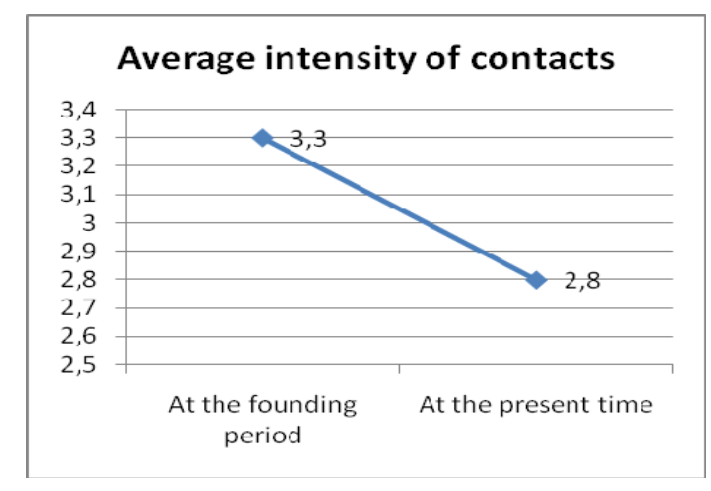


By exploring the strong multiplex ties (in which at least two types of knowledge flow), we find that in the first period (diagram 1) all of them are also very intense regarding the contacts' frequency. In terms of the organizations with a higher connection to our companies (according to the number and type of resources), in the first period we find three universities (see diagram 1, lines A, D and E), company no. 17 (line C), which is an important source of knowledge to company no. 19, and TMN (line B), a mobile phone operator. At present, both UNL and company no.17 remain crucial sources of knowledge to companies nos. 13 and 15 respectively (see diagram 2, lines A and C), reinforcing their central role in this knowledge network, as well as PT, CEO Forum and Inova-Ria, which are important for companies nos. 17, 18 and 15, respectively (lines D, E and B).

Company no. 17 is still the most central in terms of degree and betweenness, followed by nos. 23, 13 and 19 companies. UNL is the most important broker, since it links four companies, followed by Vodafone and TMN (mobile phone operators), University of Coimbra and COTEC (an organization for the promotion of innovation). Again, company no. 17 stands as the most central company. Similarly to the first period, the network centralization is quite low: $14 \%$ of degree centralization.

Table 6 - Composition of the networks

\begin{tabular}{|c|c|c|c|c|c|c|c|c|}
\hline \multirow[t]{2}{*}{$\begin{array}{l}\text { Respondent } \\
\text { companies }\end{array}$} & \multicolumn{5}{|c|}{$\begin{array}{l}\text { At the founding period (links) } \\
\text { Company }\end{array}$} & \multicolumn{3}{|c|}{ At the present time (links) } \\
\hline & University & $\begin{array}{c}\text { Company } \\
\text { from IT } \\
\text { sector }\end{array}$ & $\begin{array}{l}\text { from } \\
\text { other } \\
\text { sectors } \\
\end{array}$ & $\begin{array}{c}\text { Other } \\
\text { organizations } \\
\end{array}$ & University & $\begin{array}{l}\text { Company } \\
\text { from IT } \\
\text { sector }\end{array}$ & $\begin{array}{c}\text { Company } \\
\text { from other } \\
\text { sectors }\end{array}$ & $\begin{array}{c}\text { Other } \\
\text { organizations }\end{array}$ \\
\hline 5 & 0 & 0 & 2 & 1 & 0 & 0 & 0 & 0 \\
\hline 8 & 0 & 1 & 1 & 0 & 1 & 0 & 0 & 2 \\
\hline 9 & 1 & 0 & 1 & 0 & 1 & 0 & 0 & 0 \\
\hline 11 & 0 & 4 & 3 & 0 & 0 & 3 & 0 & 1 \\
\hline 12 & 0 & 2 & 0 & 0 & 0 & 0 & 1 & 0 \\
\hline 13 & 1 & 2 & 3 & 0 & 1 & 3 & 2 & 0 \\
\hline 14 & 1 & 0 & 1 & 0 & 2 & 0 & 0 & 0 \\
\hline 15 & 0 & 0 & 1 & 1 & 0 & 3 & 0 & 1 \\
\hline 17 & 6 & 4 & 0 & 0 & 11 & 8 & 0 & 1 \\
\hline 18 & 2 & 0 & 0 & 1 & 2 & 0 & 0 & 1 \\
\hline 19 & 1 & 1 & 1 & 1 & 1 & 5 & 3 & 0 \\
\hline 22 & 0 & 3 & 0 & 0 & 0 & 4 & 0 & 0 \\
\hline 23 & 2 & 1 & 1 & 0 & 3 & 2 & 2 & 0 \\
\hline Total & 14 & 18 & 14 & 4 & 22 & 28 & 8 & 6 \\
\hline Percentage & $28,00 \%$ & $36,00 \%$ & $28,00 \%$ & $8,00 \%$ & $34,38 \%$ & $43,75 \%$ & $12,50 \%$ & $9,38 \%$ \\
\hline
\end{tabular}


In terms of the organizations that are present in this informal network, we find that at the founding period our entrepreneurs had links mainly with other IT companies (36\%), but the links with universities (28\%) and other non-IT companies (28\% as well) were also quite important. Nowadays, the most significant change is the decrease in the proportion of links with non-IT companies (13\%) and the increase in the share of relations with other IT companies (44\%) and with universities (34\%) (see table 6).

Diagram 1 - Entrepreneurs' networks at the founding stage of the 13 companies

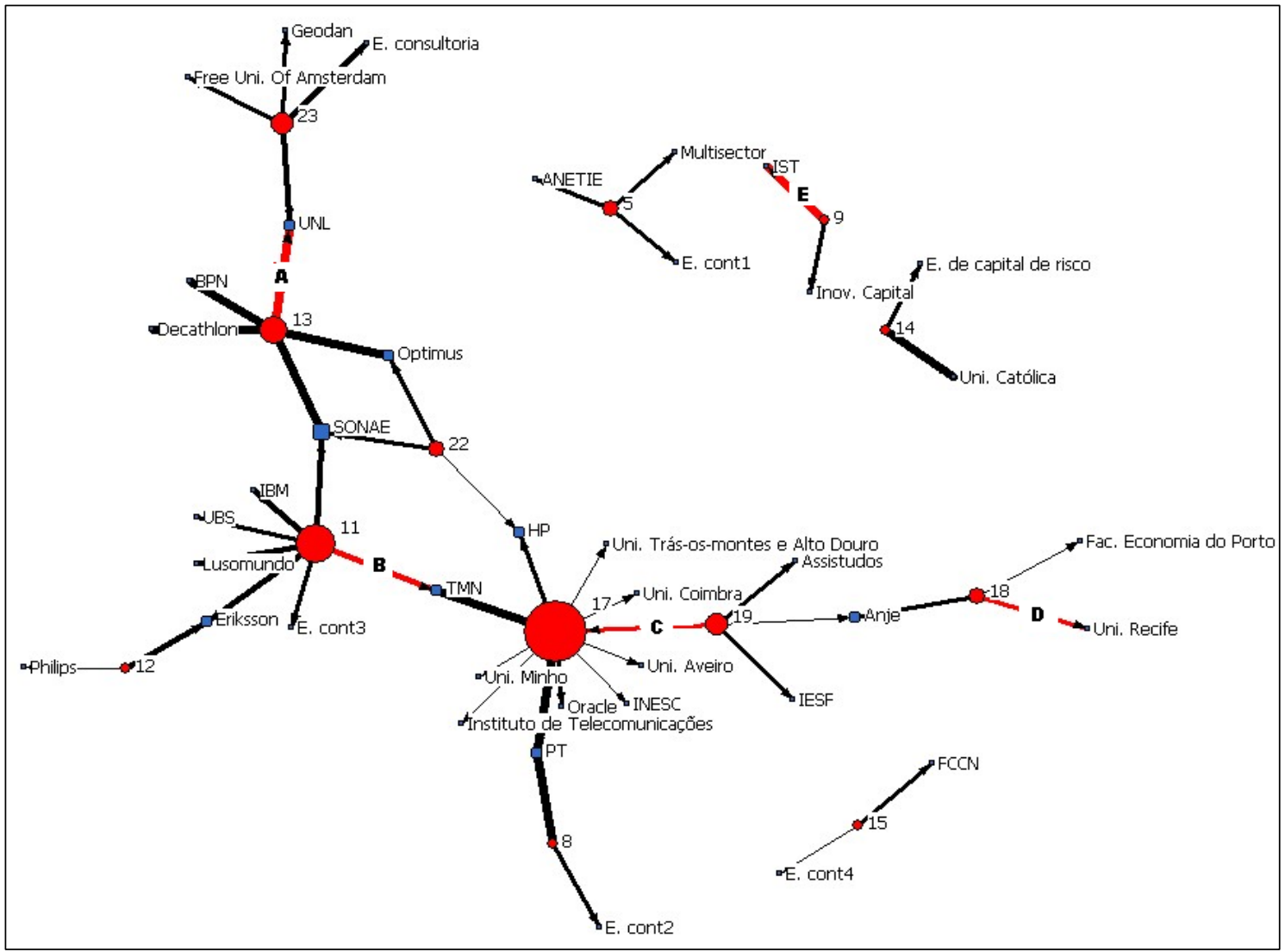

Note 1: The circles represent the respondent companies; squares represent the

organizations with which they have ties; lines represent the ties between respondent companies and other organizations.

Note 2: Thicker lines represent a higher intensity of the tie, measured by the frequency of contacts (from 1 - yearly to 5 - daily).

Note 3: Those lines (ties) that are identified by capital letters (A, B, C, ...) represent strong ties according to the intensity of the tie, measured by the number and type of resources that flow in the tie; the others represent weak ties. 
Diagram 2 - Entrepreneurs’ networks in the development stage of the 13 companies (2008)

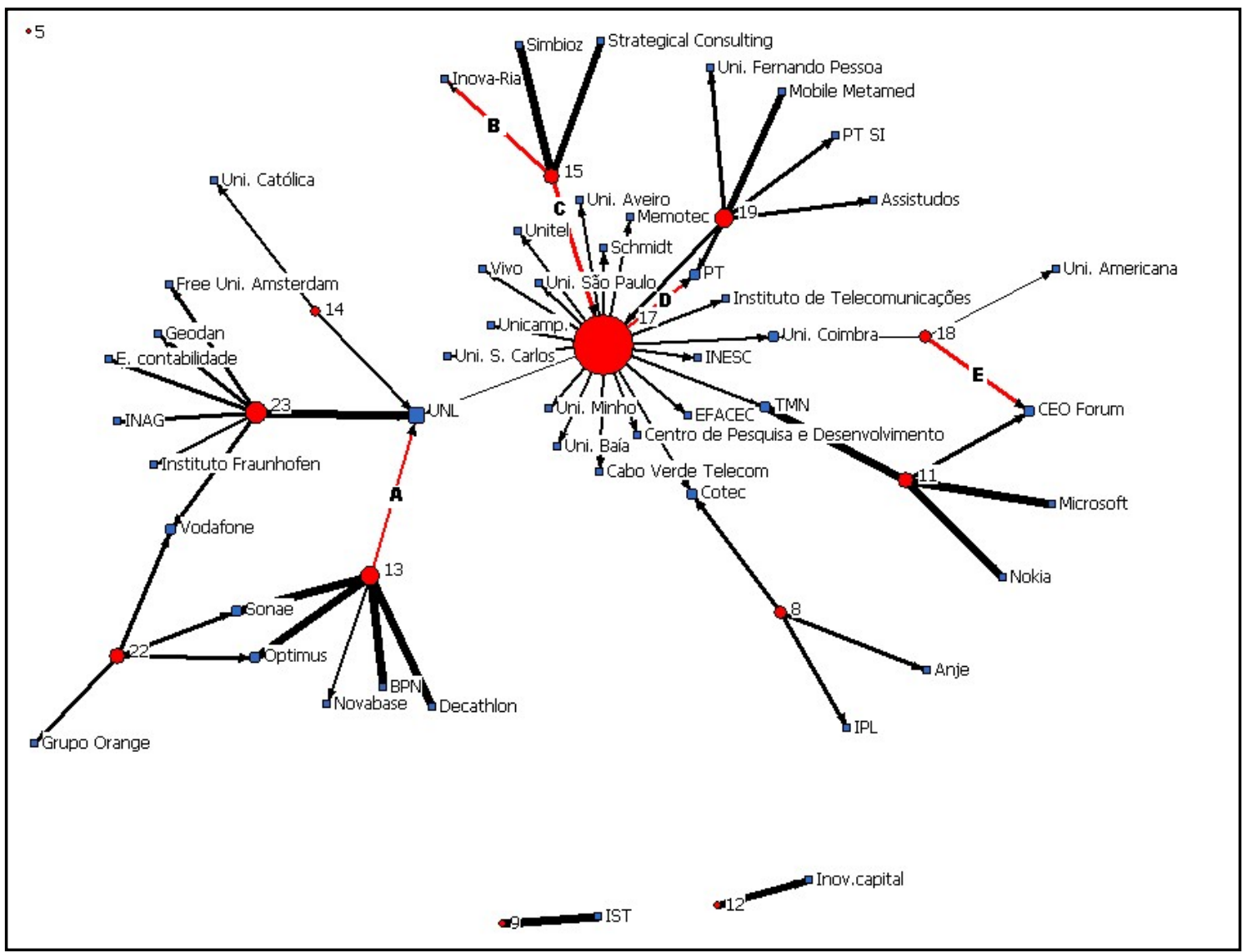

Note 1: The circles represent the respondent companies; squares represent the organizations with which they have ties; lines represent the ties between respondent companies and other organizations.

Note 2: Thicker lines represent a higher intensity of the tie, measured by the frequency of contacts (from 1 - yearly to 5 - daily).

Note 3: Those lines (ties) that are identified by capital letters (A, B, C, ...) represent strong ties according to the intensity of the tie, measured by the number and type of resources that flow in the tie; the others represent weak ties. 


\section{CONCLUSIONS}

The study of the relation between social networks and entrepreneurship was initiated in the late 1980s by a research group around Howard Aldrich (see Bruderl and Preisendorfer, 1998), and since then much research has been done (see Sousa, 2008), including many studies focusing on particular industries, such as IT and biotechnology. Drawing on this strand of literature, but also on innovation studies, the research presented here aims to contribute to the characterization of the Portuguese software for telecommunications industry through social network analysis. It has a pioneer nature due to the fact that, to our knowledge, it is the first empirical study based on evidence on the Portuguese software industry obtained and interpreted through this approach.

The first purpose of this study was to analyze the relevance of the entrepreneurs' personal networks to the performance of their companies and to their own, both at the initial stage and at the present time. As predicted in the first two hypotheses, entrepreneurs' personal networks are more important to the performance of the companies in the founding period. Nowadays, the entrepreneurs' personal networks are more important to their own performance. In order to provide a framework to our study, we have analyzed the structure and characteristics of the software for telecommunications industry in Portugal, a knowledge-intensive industry, in both periods.

Although the research questions don't present novelty to the state of the art, the use of a combined methodology might be an interesting advantage of this study. The study of the intensity of the ties between respondent companies and other organizations using two methods the frequency of contacts and the number and type of resources that flow in the tie - might add value to the empirical work since it provides more complex information about the network.

Our empirical evidence shows that networks are structured and have evolved in accordance with the main theoretical predictions (hypotheses $3 a$ and $3 b$ were confirmed), namely regarding the proportion, role and relevance of strong ties in comparison with weak ties, at the initial stage and at the present time. At the founding stage, entrepreneurs have more strong links to other organizations, and at present the percentage of weak ties increases. This network is nowadays larger and more diversified. Through strong ties, entrepreneurs have access to different sorts of in-depth knowledge and information - innovation, S\&T, management and decision-making - that are crucial to their innovative activities. Through a diversified network constituted mainly by weak ties, entrepreneurs have the possibility to obtain new, non redundant information. 
By exploring the strong multiplex ties (in which at least two types of knowledge flow) we find that in the first period (diagram 1) all of them are also very intense regarding the contacts' frequency. Currently, sometimes not so frequent relations have the potential to bring more than one type of knowledge, thus confirming that the personal networks are more mature and less dependent on the contacts' frequency.

Furthermore, we have also identified the companies and organizations that play a prime role in stirring entrepreneurship in the industry, thus contributing to its growth. Among them, public universities from the north, center and Lisbon region, research centers and IT companies (both national and multinational) are to be mentioned, as well as incubators.

Among our respondents, company no.17 emerges as a central player in the subsector. It has the highest number of links to other organizations and it also plays an important brokerage role. This company had its origins in the public sector, which helps to to explain the large number of links that this company has to public universities and domestic IT companies. These links are important to obtain novel information concerning innovation and S\&T knowledge, which are crucial types of knowledge in a knowledge-intensive industry. This company plays thus an important role in the diffusion of knowledge and innovation from universities to the private sector.

In 2007, company no. 17 had nearly 500 workers (one of the top five domestic IT companies in Portugal, regarding the number of employees) and a turnover upwards of $€ 80$ million. It spends nearly $20 \%$ of its turnover in subcontracting other IT companies and another $20 \%$ in R\&D activities. Besides being an important client for some of the companies of this sector, it also plays a relevant role as a parent organization for others. In fact, several spin-off companies have been created by former workers of this company, and they often maintain a relation with the parent company. Usually, as our empirical work shows, this is a strong relation characterized by a high frequency of contacts and used to obtain more than one type of knowledge resources.

If company no. 17 were removed from the network, the number of weak links and the connectedness of the network would decrease dramatically. In the initial network, the percentage of weak ties would then be of just $13 \%$ of total ties and at present it would slightly increase to $16 \%$.

At present, other companies such as nos. 23, 13, and 19 have more links than at the founding period, and at the same time they have succeeded in terms of growth of their turnover and number of workers. These companies have links to universities and the PT group, which, once more, confirms a) the positive association between the acquisition of new knowledge and 
growth, and b) the importance of being connected to the PT group (which had also its origins in the public sector). The PT group also appears as a core element due to the fact that it is the main client for some of these companies, usually via outsourcing, which is reflected in a strong and intense relationship with some of them.

These findings allow us to stress the relevance not only of personal networks but also of some specific entities for the creation and development of an IT industry. And it became clear in this paper that, as other authors have claimed, there is a relevant association between entrepreneurship and innovation. Since the creation of companies in an advanced sector is a necessary condition to upgrade the country's specialization pattern and to fully implement the transition to a knowledge-based economy, technological entrepreneurship becomes crucial. That is why the analysis of social networks has become intimately connected with the study of this type of entrepreneurship.

Further research will attempt at deepening the analysis presented in this article, along two main lines. The first consists of studying the formal partnerships established by the software companies either with other companies or with other entities, in order to get a full picture of the networks that, in a way, constitute the thread underlying the sector structure itself. The second line of research consists of comparing the software companies' networks with those of other knowledge-intensive sectors. Generalizations are likely to emerge, regarding not only different types of firms but also different sectors and technological regimes in relation to networks. Unveiling the implications of our study to innovation policy is also a purpose of future research. 


\section{REFERENCES}

BIRLEY, S. (1985), “The role of networks in the entrepreneurial process”, Journal of Business Venturing, 1, pp. 107-117.

BORGATTI, S. \& FOSTER, P. (2003), “The network paradigm in organizational research: A review and typology”, Journal of Management, 29 (6), pp. 991-1013.

BORGATTI, S., EVERETT, M. \& FREEMAN, L. (1999), Ucinet 6.0 Version 1.00. Natick: Analytic Technologies.

BRUDERL, J. \& PREISENDORFER, P. (1998), "Network support and success of newly founded businesses”, Small Business Economics, 10, pp. 213-225.

BUENSTORF, G. (2006), "Perception and pursuit of entrepreneurial opportunities: An evolutionary perspective”, Papers on Economics \& Evolution, Max Planck Institute of Economics, Evolutionary Economics Group, Jena, 2006-01.

BURT, R. (1992), Structural Holes, Cambridge, MA: Harvard University Press.

CANTILLON, R. (1755), "Essai sur la Nature du Commerce en Général», in Shane, S. (2003), A General Theory of Entrepreneurship: The Individual- Opportunity Nexus, Cheltenham: Edward Elgar.

CAROLIS, D. \& SAPARITO, P. (2006), "Social capital, cognition, and entrepreneurial opportunities: a theoretical framework”, Entrepreneurship Theory and Practice, 30 (1), pp. 41-56.

CASSON, M. \& WADESON, N. (2007), “The discovery of opportunities: Extending the economic theory of the entrepreneur”, Small Business Economics, 28, pp. 285-300.

COLEMAN, J. (1990), Foundations of Social Theory, Cambridge, MA: Harvard University Press.

DUBINI, P. \& ALDRICH, H. (1991), "Personal and extended networks are central to entrepreneurial process”, Journal of Business Venturing, 6, pp. 305-313.

GRANOVETTER, M. (1973), “The strength of weak ties”, American Journal of Sociology, vol.78 (6), pp. 1360-1380.

GRANOVETTER, M. (1985), "Economic action and social structure: the problem of embeddedness”, American Journal of Sociology, vol.91 (3), pp. 481-510.

GREBEL, T., PYKA, A., HANUSCH, H. (2003), "An evolutionary approach to the theory of entrepreneurship", Industry and Innovation, Vol. 10 (4), pp. 493-514.

HÉBERT, R. \& LINK, A. (1989), "In search of the meaning of entrepreneurship”, Small Business Economics, 1, pp. 39-49.

HITE, J. \& HESTERLY, W. (2001), "The Evolution of Company Networks: From 
Emergence to Early Growth of the Company”, Strategic Management Journal, 22, pp. 275-286.

KIRZNER, I. (1982), "Uncertainty, discovery and human action: A study of the entrepreneurial profile in the Misesian system”, in I. M. KIRZNER (ed.), Method, Process and Austrian Economics: Essays in Honour of Ludwig von Mises, Lexington, Mass: D. C. Heath, pp. 139-159.

KLEPPER, S. (1996), "Entry, Growth, and Innovation over the Product Life Cycle", American Economic Review, 86 (3), pp.562-583.

MUSTAR, P., RENAULT, M., COLOMBO, M., PIVA, E., FONTES, M., LOCKETT, A., WRIGHT, M., CLARYSSE, B. \& MORAY, N. (2006), "Conceptualising the heterogeneity of research-based spin-offs: A multi-dimensional taxonomy”, Reseach Policy, 35, pp.289-308.

POWELL, W. \& GRODAL, S. (2005), "Networks of Innovators”, in FAGERBERG, J., MOWERY, D. C. and NELSON, R. R. (eds.), The Oxford Handbook of Innovation, Oxford: Oxford University Press, pp. 56-85.

SCHUMPETER, J. (1934), The Theory of Economic Development: An inquiry into profits, capital, credit, interest and the business cycle, Cambridge, Mass: Harvard University Press.

SCHUMPETER, J. (1942), Capitalism, Socialism and Democracy, London and New York: Routledge.

SCOTT, J. (2000), Social Network Analysis - A Handbook, London: Sage Publications.

SHANE, S. (2003), A General Theory of Entrepreneurship: The Individual- Opportunity Nexus, Cheltenham: Edward Elgar.

SORENSON, O., RIVKIN J. \& FLEMING, Lee. (2006), "Complexity, Networks and Knowledge Flow”, Research Policy 35, no. 7, pp. 994-1017.

SOUSA, C. (2008), "Redes Sociais, Capital Social e Empreendedorismo: Questões teóricas e metodológicas”, Working Paper 2008/68, DINÂMIA, Lisbon.

WASSERMAN S. \& FAUST, K. (1994), "Social Network Analysis: Methods and Applications”, Cambridge: Cambridge University Press.

WILLIAMSON, O. (1975), Markets and Hierarchies: Analysis and Antitrust Implication, New York: The Free Press.

ZHAO, L. \& ARAM, J. (1995), "Networking and growth of young technology-intensive ventures in China”, Journal of Business Venturing, 10, pp. 349-370. 